\title{
Editorial v8n1
}

Sofia Sampaio, Rui Lopes, Arlindo Horta, Jorge Palinhos e Catarina Laranjeiro

Este é o primeiro número a cargo do conselho editorial que foi eleito no dia 20 de junho de 2020, na Assembleia Geral da AIM - pela primeira vez, na sua história, realizada por teleconferência. A razão é bem conhecida: o avanço do novo coronavírus detetado na China, no final de 2019, que suscitou restrições, mais ou menos severas, nas populações de todo o mundo, culminando no cancelamento de viagens e no adiamento de milhares de eventos académicos e sociais - incluindo o X Encontro da AIM, adiado para Maio de 2021.

A Aniki é, desde a sua origem, uma revista profundamente implicada nas chamadas 'novas tecnologias'. Com edição exclusivamente eletrónica, disponível em acesso aberto, grande parte do seu trabalho editorial é desenvolvido numa plataforma (Open Journal System), também ela eletrónica e em linha. Não se pode, portanto, dizer que os efeitos perturbadores que a pandemia teve no mundo do trabalho - estimulando, ou mesmo impondo, o regime de teletrabalho e o uso das tecnologias digitais a níveis nunca antes imaginados - se tenham feito sentir na revista. À exceção de um ou outro episódio caricato (como receber pareceres destinados a outras revistas!) ou o agravamento de atrasos nos prazos de entrega de pareceres e revisões (atrasos que, infelizmente, não são de agora), o trabalho decorreu dentro dos parâmetros habituais, com volume idêntico de submissões e, do nosso lado, o mesmo sentido de responsabilidade. E não parou.

Em funções a partir de meados de Julho, após a publicação do último número coordenado pelo conselho editorial cessante, os novos editores rapidamente se adaptaram aos fluxos de trabalho e puseram mãos à obra. 0 dossier temático - lançado pela equipa anterior - fez o seu caminho. 0 tema não podia ter sido mais oportuno - 'Festivais de cinema e os seus contextos socioculturais' -, como se pôde perceber pelo elevado número de submissões que a chamada de trabalhos atraiu. Num processo com várias etapas, que muito beneficiou do conhecimento especializado das editoras 
convidadas - Aida Vallejo (Universidade do País Basco) e Tânia Leão (Instituto de Sociologia da Universidade do Porto) -, seis textos foram selecionados para a avaliação por pares. Foram, depois, revistos pelos autores, em conformidade com os pareceres recebidos, as indicações das editoras convidadas e as sugestões da Aniki. 0 resultado deste trabalho pode ser apreciado nas páginas que agora se publicam. A foto da capa é de Estrella Sendra e capta um momento do Banlieu Films Festival (Senegal, 2015), sobre o qual a autora escreveu para este dossier.

As secções da revista são as mesmas, funcionando em regime de chamada de trabalhos permanentemente aberta. Vale a pena lembrar que tipo de textos a Aniki procura para cada uma delas. Assim, a rubrica 'Ensaios' (a única, para além do dossier temático, que conta com arbitragem por pares) continua dedicada a textos que contemplem não apenas uma variedade de abordagens ao estudo da imagem em movimento, mas a própria pluralidade de objetos que se inserem nesse campo. Esta edição reflete essa diversidade através de dois ensaios sobre obras cinematográficas díspares - o filme experimental A Dança dos Paroxismos (1929) e a série de terror em torno da personagem Zé do Caixão, que se estendeu dos anos 60 ao século XXI - e um outro sobre uma websérie amadora. A análise destes objetos conduz a discussões sobre os vícios interpretativos a propósito do cinema português, a Primeira Vanguarda Francesa, a estética da precariedade, a categoria de Queer Caboclo, a conceptualização foucaultiana da anormalidade e a articulação do género terror com a história e a sociedade brasileiras. A secção 'Entrevistas' partilha o mesmo interesse pela pluralidade de abordagens e objetos que circunscrevem o universo do que habitualmente chamamos 'imagens em movimento', pretendendo dar voz a cineastas, técnicos, teóricos e pedagogos que nos ofereçam uma perspetiva interessante sobre o contexto do seu trabalho. Exemplo disso é a entrevista que publicamos, neste número, com a curadora eslovena Nataša PetrešinBachelez, onde se aborda o que poderá ser uma curadoria sustentável ou a necessidade de descolonizar as práticas e as instituições museológicas. $\mathrm{Na}$ esteira do trabalho anterior, a secção das 'Recensões' continua a incidir sobre livros recentemente publicados que se enquadrem dentro do âmbito da diversidade de interesses da revista. Tal diversidade é evidente nas quatro recensões deste número, em que encontramos temas tão variados como mulheres realizadoras portuguesas, o marxismo no cinema, o design de interação em videojogos e as relações de classe no cinema brasileiro. Por fim, a secção 'Exposições e Festivais de Cinema' convida a um pensamento crítico sobre este tipo de eventos, incluindo os seus projetos curatoriais e estratégias de engajamento com o público, refletindo como estes dialogam 
com a complexa realidade social na qual se inserem. Provenientes de três continentes - África, América, e Europa - os textos do presente número partilham um compromisso com as abordagens pós-coloniais, com as quais o campo das artes visuais e do cinema tem vindo a consolidar frutíferas sinergias.

Lembramos que todos os textos devem ser originais e inéditos e recomendamos vivamente que os autores consultem as 'Políticas de Secção' e as 'Instruções para Autores', disponíveis no sítio da revista. Deverão contactar-nos apenas no final dessa consulta e somente no caso de subsistirem dúvidas. Este conselho editorial está empenhado em melhorar a informação disponibilizada no sítio da Aniki - nomeadamente no que diz respeito à clareza das regras de formatação dos textos que nos são submetidos. Os compromissos que a revista assumiu com bases de indexação internacionais tornam imprescindível o seguimento das normas de referenciação bibliográfica e filmográfica. Note-se que é $d a$ responsabilidade dos autores garantir, desde a fase inicial da submissão dos textos, que todos os requisitos - temáticos, científicos e formais - são cumpridos.

Por fim, neste número, apresentamos mudanças no grafismo da revista, aplicadas aos documentos que publicamos, individualmente, em formato de PDF. 0 que nos motivou foi a decisão de estes documentos passarem a incluir os resumos e as palavras-chave nas duas línguas obrigatórias da revista - português e inglês - e numa outra que tenha sido adoptada pelos autores com o consentimento prévio dos editores. Para além de reforçar a capacidade de preservação destes dados (antes apenas disponibilizados em formato eletrónico, no sítio da revista), a alteração que agora se implementa pretendeu também valorizar este tipo de informação, cada vez mais importante quer no universo das revistas científicas quer no meio académico. Efetivamente, saber resumir, em poucas palavras e com a máxima clareza, o conteúdo de um texto é uma habilidade rara, que merece ser amplamente reconhecida e incentivada. Agradecemos à Direção da AIM, em especial à Catarina Maia, o bom acolhimento desta ideia e o ter-nos colocado em contacto com o designer Pedro Pereira, com o qual trabalhámos para o resultado que agora vem a público. Esperamos que a nova imagem seja do agrado de todos os que nos leem. 